\title{
Two neurologic facets of CTLA4-related haploinsufficiency
}

Xavier Ayrignac, MD, PhD,* Radjiv Goulabchand, MD,* Eric Jeziorski, MD, PhD, Patricia Rullier, MD, Clarissa Carra-Dallière, MD, Claire Lozano, MD, Pierre Portales, MD, Thierry Vincent, MD, PhD, Jean François Viallard, MD, PhD, Nicolas Menjot de Champfleur, MD, PhD, Frédéric Rieux-Laucat, PhD, Caroline Besnard, MD, Michel Koenig, MD, PhD, Claire Guissart, PhD, Pierre Labauge, MD, PhD, and Philippe Guilpain, MD, PhD

Neurol Neuroimmunol Neuroinflamm 2020;7:e751. doi:10.1212/NXI.0000000000000751

\author{
Correspondence \\ Dr. Ayrignac \\ xavier.ayrignac@yahoo.fr
}

\begin{abstract}
\section{Objective}

To describe the clinical and radiologic neurologic characteristics of patients with cytotoxic T-lymphocyte antigen-4 (CTLA4) haploinsufficiency.
\end{abstract}

\section{Methods}

Three patients from 2 families had neurologic manifestations in the context of CTLA4 haploinsufficiency. Their clinical and MRI findings are presented.

\section{Results}

A 16-year-old boy with a previous diagnosis of combined immunodeficiency presented with severe recurrent episodes of headaches, motor deficit, and seizures associated with waxing and waning gadolinium-enhancing FLAIR cortical/juxtacortical hyperintensities. His sister, who also had combined immunodeficiency, had a brain MRI when she was aged 13 years due to recent headaches and transient right hemianopsia. It revealed a gadolinium-enhancing left occipital white matter hyperintensity. Another 49-year-old woman had progressive visual loss and cerebellar ataxia in the context of recurrent pulmonary infections. All 3 patients were found to have inherited CTLA4 haploinsufficiency. Patient 1's general condition and neurologic manifestations were completely controlled with abatacept (CTLA4-Ig).

\section{Conclusions}

These cases suggest that in addition to the variable clinical penetrance and wide spectrum of CTLA4 haploinsufficiency, its neurologic spectrum is broad, ranging from recurrent tumefactive lesions to progressive deficits including cerebellar ataxia and optic atrophy with leukoencephalopathy. These phenotypes must be recognized, and should lead to a complete immunologic workup, because potentially effective targeted immunotherapy exists.

\footnotetext{
*X. Ayrignac and R. Goulabchand contributed equally to this manuscript as first coauthors.

From the Department of Neurology (X.A., C.C.-D., P.L.), Montpellier University Hospital, INSERM, Univ Montpellier, Montpellier; Internal Medicine Department (R.G.), Caremeau University Hospital, Nimes; Department of Paediatrics (E.J.), Montpellier University Hospital, INSERM, Univ Montpellier; Médecine interne multi-organes (P.R., P.G.), Montpellier University Hospital, INSERM, Univ Montpellier; Department of Immunology (C.L., P.P., T.V.), Montpellier University Hospital, INSERM, Univ Montpellier; Internal Medicine Department (J.F.V.), Bordeaux University Hospital, Univ Bordeaux; Department of Neuroradiology (N.M.C.), Montpellier University Hospital, INSERM, Univ Montpellier; Université de Paris (F.R.-L., C.B.), Imagine institute, Laboratory of Immunogenetics of Pediatric Autoimmune Diseases, INSERM UMR 1163, Paris; and Laboratory of Molecular Genetics (M.K., C.G.), Montpellier University Hospital, INSERM, Univ Montpellier, France.
}

Go to Neurology.org/NN for full disclosures. Funding information is provided at the end of the article.

The Article Processing Charge was funded by the authors.

This is an open access article distributed under the terms of the Creative Commons Attribution-NonCommercial-NoDerivatives License 4.0 (CC BY-NC-ND), which permits downloading and sharing the work provided it is properly cited. The work cannot be changed in any way or used commercially without permission from the journal. 


\section{Glossary}

CTLA4 = cytotoxic T-lymphocyte antigen-4; ITP = immune thrombocytopenia.

Cytotoxic T-lymphocyte antigen-4 (CTLA4) is a major negative regulator of T-cell immune response. ${ }^{1,2}$ It has recently been shown that heterozygous mutations in the CTLA4 gene can lead to CTLA4 insufficiency, characterized by a wide range of clinical manifestations including autoimmune diseases, infections, and lymphoproliferation..$^{3-5}$ Neurologic manifestations can occur in almost $30 \%$ of cases. ${ }^{5}$ Nevertheless, their clinical and radiologic characteristics have never been thoroughly described, notably in adult patients. ${ }^{5,6}$

We hereby report on 3 patients from 2 separate families with CTLA4 insufficiency who harbored distinct clinical characteristics, suggesting that its neurologic spectrum is broader than previously suggested.

\section{Methods}

Patients were identified from the reference center for adultonset inherited leukoencephalopathies, Department of Neurology, Montpellier University Hospital, Montpellier, France.
Clinical and MRI data were analyzed and are described in the article.

\section{Standard protocol approvals, registrations, and patient consents}

Montpellier University Hospital Institutional Review Board approved this study.

\section{Date availability}

Anonymized data will be shared by the corresponding author on reasonable request from any qualified investigator.

\section{Results}

\section{Case reports}

\section{Patient 1}

A 16-year-old boy (figure 1A, III6) had a previous diagnosis of combined immunodeficiency characterized by autoimmune diseases, repeated skin infections and bacterial pneumonias, and lymphoproliferative disorder (table and figure 1B). The

\section{Figure 1 Family 1}
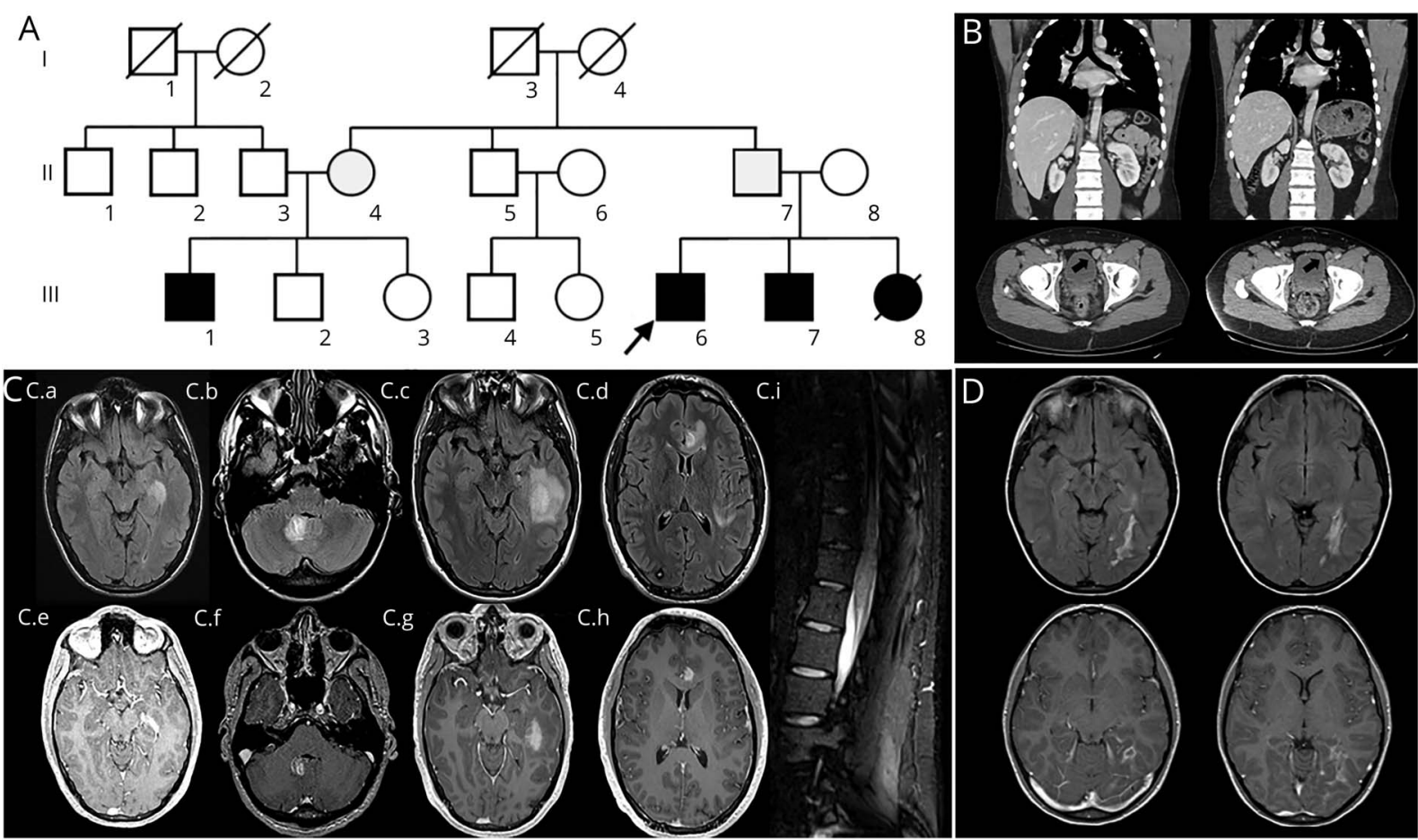

(A) Family 1 pedigree: the arrow indicates patient 1 , squares $=$ males, circles $=$ females, black-filled symbol $=$ symptomatic patients, gray-filled symbol $=$ asymptomatic carrier, and strikethrough = deceased patients. (B) Patient's abdominal and pelvic CT showing enlarged liver and lymph nodes (arrow) (left panel), which decreased (respectively from $213 \mathrm{~mm}$ to $190 \mathrm{~mm}$ and $23 \mathrm{~mm}$ to $18 \mathrm{~mm}$ ) after abatacept therapy (right panel). (C) Regular brain MRI scans repeated from age 16 to 25 years disclosed multiple nodular cortical/juxtacortical FLAIR hyperintensities (C.a-C.d) with gadolinium enhancement (C.e-C.h). (C.i) Spinal cord MRI evidenced diffuse conus medullaris hyperintensities. (D) Patient 1's sister aged 15 years. The MRI showed an infiltrative occipital white matter lesion with gadolinium enhancement. 


\begin{tabular}{|c|c|c|c|}
\hline Patient & Patient 1 (III6) & Patient 2 (III8) & Patient 3 \\
\hline Age at onset & 5 & 2 & 42 \\
\hline $\begin{array}{l}\text { Age at onset of autoimmune } \\
\text { manifestations }\end{array}$ & 11 & 2 & - \\
\hline \multirow{6}{*}{$\begin{array}{l}\text { Autoimmune and inflammatory } \\
\text { manifestations }\end{array}$} & ITP & Type 1 diabetes & \\
\hline & Type 1 diabetes & Evan syndrome & \\
\hline & & Bilateral uveitis & \\
\hline & & Vitiligo & \\
\hline & & Aseptic meningitis & \\
\hline & & Autoimmune ovaritis & \\
\hline Autoantibodies & $\begin{array}{l}\text { Langerhans islet cell antibodies, antinuclear, antithyroperoxidase, } \\
\text { antithyroglobulin, anticardiolipin antibodies, and Coombs test }\end{array}$ & & Rheumatoid factor \\
\hline Immunologic profile & $\begin{array}{l}\text { IgA and IgM insufficiency; low IgG2 and IgG4 subclasses; low T and NK } \\
\text { lymphocyte count; low levels of antimeasles and antimumps antibodies }\end{array}$ & $\begin{array}{l}\text { IgG and IgM insufficiency, unmeasurable } \\
\text { IgA level; low B and NK lymphocyte count }\end{array}$ & $\begin{array}{l}\text { IgA and IgM insufficiency; reduced IgG2 level and } \\
\text { unmeasurable IgG4 level; low B, T, and NK lymphocyte } \\
\text { count }\end{array}$ \\
\hline Age at onset of repeated infections & 5 & 2 & 42 \\
\hline \multirow[t]{6}{*}{ Infections } & Molluscum contagiosum & Myocarditis (parvovirus) & ENT \\
\hline & Dermatophytosis & Zona & Lung (bronchiectasis) \\
\hline & Pneumonias & Pneumococcal meningitis & Papillomavirus \\
\hline & Anal abscess & Recurrent bacterial pneumonia & \\
\hline & Septic arthritis & & \\
\hline & Balanitis & & \\
\hline \multirow{3}{*}{ Lymphoproliferative disorder } & Multiple lymph node enlargement & Multiple lymph node enlargement & - \\
\hline & Interstitial pneumonitis & Kidney infiltrates & \\
\hline & & Interstitial pneumonitis & \\
\hline
\end{tabular}


immunologic profile was consistent with a combined immune deficiency (table). When he was aged 16 years, he presented with severe recurrent headaches, but a complete workup including a brain MRI was normal. Since that episode, he had recurrent headaches: at age 21 years, a new brain MRI disclosed multiple hyperintense cortical and juxtacortical FLAIR lesions with gadolinium enhancement (figure 1C). Repeated CSF studies disclosed a high white blood cell count ( $40-150$ cells $/ \mu \mathrm{L}$, lymphocytes) and a high protein level $(72-81 \mathrm{mg} / \mathrm{dL})$.

Because of immune thrombocytopenia (ITP), he received repeated courses of oral steroids associated with rituximab. This strategy remained ineffective: his global health status remained unstable with recurrent mucocutaneous bleeding and epistaxis. Two years later, he presented with lower limb weakness and right partial motor seizures. Multiple brain MRIs revealed recurrent brain and spinal cord lesions (figure 1C). A gene panel analysis identified a heterozygous deletion (c.109+1093_558-513del) in the CTLA4 gene.

He was then treated with abatacept (CTLA4-Ig), and his general condition progressively improved (complete remission of ITP and bleedings, along with a dramatic reduction in the volume of lymph nodes and liver (figure 1B). Subsequent brain MRI follow-up did not reveal any additional lesions (42 months' follow-up, image not shown).

\section{Patient 2}

Patient 1's sister (figure 1A, III8), who carried the same mutation, had unexplained brain lesions (figure 1D) identified in the context of headaches and transient hemianopsia treated with steroid pulse when she was aged 13 years. From age 2 years, she had been having severe lymphoproliferation, autoimmune manifestations, and multiple infections (table). She was thus diagnosed with combined immunodeficiency. However, for years, multiple immunosuppressive therapies including cyclophosphamide, rituximab, and immunoglobulin supplementation remained ineffective on her global health status. She died at age 16 years due to severe pneumococcal sepsis.

It should be noted that several of their relatives (figure 1A) including their brother and their unaffected father carried the same mutation.

\section{Patient 3}

A 54-year-old woman presented with walking difficulties associated with bilateral axonal optic neuropathy and bladder urgency. Although optic neuropathy progressively worsened, resulting in severe bilateral vision loss (from 160/200 and $140 / 200$ to $30 / 200$ bilaterally within 4 years), she progressively developed severe upper limb dysmetria and speech/swallowing disorders. Clinical examination showed spastic tetraparesis with unsteadiness, marked dysmetria, and head tremor. Cognitive testing was normal. A brain MRI performed at age 55 years identified subtle white matter and 
deep basal ganglia FLAIR hyperintensities, as well as cerebellar atrophy and optic atrophy (figure 2, A-D). Another MRI performed 5 years later disclosed a dramatic increase in FLAIR hyperintensities (figure 2, E-H). A complete workup looking for autoimmune, paraneoplastic, and infectious causes was negative. CSF analysis disclosed normal cell count and protein level with 4 CSF-specific oligoclonal bands. A miniexome analysis identified a heterozygous stop codon within exon 2 of the CTLA4 gene (c.151C>T; p.Arg51*).

The patient's previous family history was unremarkable. However, her own medical history revealed recurrent infections going back to when she was aged 40 years. A complete immunologic workup identified both IgA and IgG deficiency. She thus began monthly supplementation with IV immunoglobulin at age 50 years. This treatment regimen contributed to reduce the frequency of ear, nose, and throat as well as lung infections. Treatment with abatacept was initiated in August 2019.

\section{Discussion}

We report a complete description of the clinical and radiologic characteristics of neurologic involvement in the context of CTLA4 gene haploinsufficiency. These features may occur from the onset of adolescence to late adulthood, either as infiltrating lymphoproliferative lesions or, more surprisingly, as progressive symptoms mimicking genetic neurodegenerative disorders, including progressive cerebellar ataxia and inherited leukoencephalopathies. ${ }^{5}$

Although CNS lesions have been described in almost 30\% of patients with CTLA4 insufficiency, the neurologic spectrum seems to be broad, ranging mainly from autoimmune encephalitis and perivascular lymphocytic infiltration to inflammatory disorders, optic neuritis, and lymphoproliferative disorders with CNS infiltration. ${ }^{3-7}$ Whether our patients' neurologic involvement, notably in patients 1 and 2, is caused by an autoimmune reaction or by a lymphoproliferative process is not clear. Unfortunately, despite the presence of subtle inflammatory CSF changes in patients 1 and 3, it is difficult to favor 1 mechanism, notably in the absence of EBV PCR and pathologic analysis.

Surprisingly, the clinicoradiologic phenotype seen in patient 3 was clearly different from previously published cases, as it was mainly characterized by (1) the progressive development of cerebellar ataxia and visual loss and (2) the presence of bilateral and symmetrical white matter changes, reminiscent of those seen in inherited leukodystrophies/leukoencephalopathies. ${ }^{8,9}$ Although we cannot exclude the highly unlikely presence of 2 very rare genetic disorders in a same patient, multiple panel gene excluded the main known causes of inherited leukoencephalopathy, cerebellar ataxia, and mitochondrial diseases.

Although our patients had been diagnosed with combined immunodeficiency years before neurologic manifestations, it is noticeable that in patient 3 , the onset of symptoms occurred in her 40s and only preceded neurologic involvement by 5 years. Moreover, it has been suggested that neurologic symptoms can reveal CTLA4 insufficiency in almost $5 \%$ of patients. ${ }^{5,7}$ Consequently, irrespective of the neurologic phenotype (which can be extremely varied), CTLA4 insufficiency and other inherited immunodeficiency should be suspected, whatever the temporal relationship between the onset of systemic and neurologic symptoms. A complete examination and a blood immunologic workup, including a complete lymphocyte phenotyping and IgG subclass measurement, should thus be performed to gather evidence in favor of a potential inherited immunodeficiency.

In addition, the search for CTLA4 insufficiency is strongly justified by the possibility of using targeted therapy,

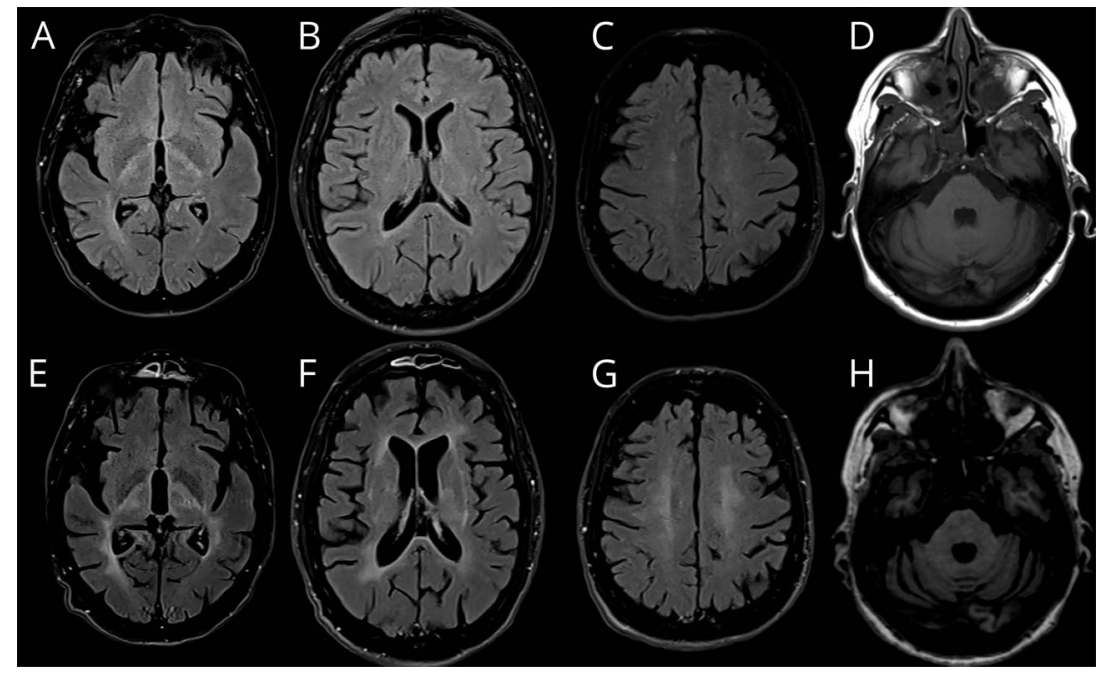

MRI revealed diffuse white matter and basal ganglia FLAIR hyperintensities (A-C and E-G) and cerebellar atrophy $(D$ and $H)$, which progressively worsened from age 52 years (upper panel) to 56 years (lower panel). 
i.e., abatacept. Patients 1 and 3 were treated with abatacept, as recently proposed. ${ }^{5,10}$ In patient 1 , this resulted in a marked improvement of systemic and biological conditions associated with stability of the CNS MRI lesion load. Unfortunately, patient 3's follow-up was too short to identify any meaningful neurologic improvement, but the IV immunoglobulin supplementation could be stopped shortly after the beginning of abatacept treatment.

Our cases suggest that the range of neurologic manifestations associated with CTLA4 insufficiency may be wide and not merely restricted to lymphoproliferative/ autoimmune systemic manifestations. Any unexplained neurologic condition consistent with those presented herein, notably in the context of lymphoproliferative disorder, autoimmunity, or immunodeficiency, should benefit from extended workup to identify inherited combined immunodeficiency that can benefit from today's available potentially effective therapy.

\section{Acknowledgment}

The authors thank Teresa Sawyers for reading and revising the English wording of this manuscript.

\section{Study funding}

No targeted funding reported.

\section{Disclosure}

The authors report no disclosures. Go to Neurology.org/NN for full disclosures.

\section{Publication history}

Received by Neurology: Neuroimmunology \& Neuroinflammation March 26, 2020. Accepted in final form April 15, 2020.

Appendix Authors

\begin{tabular}{lll}
\hline Name & Location & Contribution \\
\hline $\begin{array}{l}\text { Xavier Ayrignac, } \\
\text { MD, PhD }\end{array}$ & $\begin{array}{l}\text { Montpellier } \\
\text { University } \\
\text { Hospital }\end{array}$ & $\begin{array}{l}\text { Data collection, design } \\
\text { and conceptualization of the } \\
\text { study, and drafting } \\
\text { and reviewing of the } \\
\text { manuscript }\end{array}$ \\
\hline $\begin{array}{l}\text { Radjiv } \\
\text { Goulabchand, MD }\end{array}$ & $\begin{array}{l}\text { Nimes } \\
\text { Hospital }\end{array}$ & $\begin{array}{l}\text { Data collection, design and } \\
\text { conceptualization of the study, } \\
\text { and drafting and reviewing of the } \\
\text { manuscript }\end{array}$ \\
\hline $\begin{array}{l}\text { Eric Jeziorski, MD, } \\
\text { PhD }\end{array}$ & $\begin{array}{l}\text { Montpellier } \\
\text { University } \\
\text { Hospital }\end{array}$ & $\begin{array}{l}\text { Data collection and drafting and } \\
\text { reviewing of the manuscript }\end{array}$ \\
\hline $\begin{array}{l}\text { Patricia Rullier, } \\
\text { MD }\end{array}$ & $\begin{array}{l}\text { Montpellier } \\
\text { University } \\
\text { Hospital }\end{array}$ & $\begin{array}{l}\text { Data collection and drafting and } \\
\text { reviewing of the manuscript }\end{array}$ \\
\hline $\begin{array}{l}\text { Clarisse Carra- } \\
\text { Dallière, MD }\end{array}$ & $\begin{array}{l}\text { Montpellier } \\
\text { University } \\
\text { Hospital }\end{array}$ & $\begin{array}{l}\text { Data collection and drafting and } \\
\text { reviewing of the manuscript }\end{array}$ \\
\hline
\end{tabular}

Appendix (continued)

\begin{tabular}{|c|c|c|}
\hline Name & Location & Contribution \\
\hline Claire Lozano, MD & $\begin{array}{l}\text { Montpellier } \\
\text { University } \\
\text { Hospital }\end{array}$ & $\begin{array}{l}\text { Data collection and drafting and } \\
\text { reviewing of the manuscript }\end{array}$ \\
\hline $\begin{array}{l}\text { Pierre Portales, } \\
\text { MD }\end{array}$ & $\begin{array}{l}\text { Montpellier } \\
\text { University } \\
\text { Hospital }\end{array}$ & $\begin{array}{l}\text { Data collection and drafting and } \\
\text { reviewing of the manuscript }\end{array}$ \\
\hline $\begin{array}{l}\text { Thierry Vincent, } \\
\text { MD, PhD }\end{array}$ & $\begin{array}{l}\text { Montpellier } \\
\text { University } \\
\text { Hospital }\end{array}$ & $\begin{array}{l}\text { Drafting and reviewing of the } \\
\text { manuscript }\end{array}$ \\
\hline $\begin{array}{l}\text { Jean François } \\
\text { Viallard, MD, PhD }\end{array}$ & $\begin{array}{l}\text { Montpellier } \\
\text { University } \\
\text { Hospital }\end{array}$ & $\begin{array}{l}\text { Drafting and reviewing of the } \\
\text { manuscript }\end{array}$ \\
\hline $\begin{array}{l}\text { Nicolas Menjot de } \\
\text { Champfleur, MD, } \\
\text { PhD }\end{array}$ & $\begin{array}{l}\text { Montpellier } \\
\text { University } \\
\text { Hospital }\end{array}$ & $\begin{array}{l}\text { Drafting and reviewing of the } \\
\text { manuscript }\end{array}$ \\
\hline $\begin{array}{l}\text { Frédéric Rieux- } \\
\text { Laucat, PhD }\end{array}$ & $\begin{array}{l}\text { Imagine } \\
\text { Institute }\end{array}$ & $\begin{array}{l}\text { Data collection and drafting and } \\
\text { reviewing of the manuscript }\end{array}$ \\
\hline $\begin{array}{l}\text { Caroline Besnard, } \\
\text { MD }\end{array}$ & $\begin{array}{l}\text { Montpellier } \\
\text { University } \\
\text { Hospital }\end{array}$ & $\begin{array}{l}\text { Data collection and drafting and } \\
\text { reviewing of the manuscript }\end{array}$ \\
\hline $\begin{array}{l}\text { Michel Koenig, } \\
\text { MD, PhD }\end{array}$ & $\begin{array}{l}\text { Montpellier } \\
\text { University } \\
\text { Hospital }\end{array}$ & $\begin{array}{l}\text { Data collection and drafting and } \\
\text { reviewing of the manuscript }\end{array}$ \\
\hline $\begin{array}{l}\text { Claire Guissart, } \\
\text { PhD }\end{array}$ & $\begin{array}{l}\text { Montpellier } \\
\text { University } \\
\text { Hospital }\end{array}$ & $\begin{array}{l}\text { Data collection and drafting and } \\
\text { reviewing of the manuscript }\end{array}$ \\
\hline $\begin{array}{l}\text { Pierre Labauge, } \\
\text { MD, PhD }\end{array}$ & $\begin{array}{l}\text { Montpellier } \\
\text { University } \\
\text { Hospital }\end{array}$ & $\begin{array}{l}\text { Data collection and drafting and } \\
\text { reviewing of the manuscript }\end{array}$ \\
\hline $\begin{array}{l}\text { Philippe Guilpain, } \\
\text { MD, PhD }\end{array}$ & $\begin{array}{l}\text { Montpellier } \\
\text { University } \\
\text { Hospital }\end{array}$ & $\begin{array}{l}\text { Data collection and drafting and } \\
\text { reviewing of the manuscript }\end{array}$ \\
\hline
\end{tabular}

\section{References}

1. Gardner D, Jeffery LE, Sansom DM. Understanding the CD28/CTLA-4 (CD152) pathway and its implications for costimulatory blockade. Am J Transpl 2014;14: 1985-1991.

2. Walker LSK, Sansom DM. The emerging role of CTLA4 as a cell-extrinsic regulator of T cell responses. Nat Rev Immunol 2011;11:852-863.

3. Schubert D, Bode C, Kenefeck R, et al. Autosomal dominant immune dysregulation syndrome in humans with CTLA4 mutations. Nat Med 2014;20 1410-1416.

4. Kuehn HS, Ouyang W, Lo B, et al. Immune dysregulation in human subjects with heterozygous germline mutations in CTLA4. Science 2014;345:1623-1627.

5. Schwab C, Gabrysch A, Olbrich P, et al. Phenotype, penetrance, and treatment of 133 cytotoxic T-lymphocyte antigen 4-insufficient subjects. J Allergy Clin Immunol 2018; 142:1932-1946.

6. Buchbinder D, Seppanen M, Rao VK, Uzel G, Nugent D. Clinical challenges: identification of patients with novel primary immunodeficiency syndromes. J Pediatr Hematol Oncol 2018;40:e319-e322.

7. Watson LR, Slade CA, Ojaimi S, et al. Pitfalls of immunotherapy: lessons from a patient with CTLA-4 haploinsufficiency. Allergy Asthma Clin Immunol 2018 Available at: aacijournal.biomedcentral.com/articles/10.1186/s13223-018-0272-7. Accessed December 15, 2019.

8. Labauge P, Carra-Dalliere C, Menjot de Champfleur N, Ayrignac X, BoespflugTanguy O. MRI pattern approach of adult-onset inherited leukoencephalopathies. Neurol Clin Pract 2014;4:287-295.

9. Ayrignac X, Carra-Dalliere C, Menjot de Champfleur N, et al. Adult-onset genetic leukoencephalopathies: a MRI pattern-based approach in a comprehensive study of 154 patients. Brain J Neurol 2015;138:284-292.

10. van Leeuwen EM, Cuadrado E, Gerrits AM, Witteveen E, de Bree GJ. Treatment of intracerebral lesions with abatacept in a CTLA4-haploinsufficient patient. J Clin Immunol 2018;38:464-467. 


\section{Neurology \\ Neuroimmunology \& Neuroinflammation}

Two neurologic facets of CTLA4-related haploinsufficiency

Xavier Ayrignac, Radjiv Goulabchand, Eric Jeziorski, et al.

Neurol Neuroimmunol Neuroinflamm 2020;7;

DOI 10.1212/NXI.0000000000000751

This information is current as of June 4, 2020

\section{Updated Information \& Services}

References

Citations

Subspecialty Collections

Permissions \& Licensing

Reprints including high resolution figures, can be found at:

http://nn.neurology.org/content/7/4/e751.full.html

This article cites 9 articles, 2 of which you can access for free at: http://nn.neurology.org/content/7/4/e751.full.html\#\#ref-list-1

This article has been cited by 3 HighWire-hosted articles: http://nn.neurology.org/content/7/4/e751.full.html\#\#otherarticles

This article, along with others on similar topics, appears in the following collection(s):

All Genetics

http://nn.neurology.org//cgi/collection/all_genetics

Leukodystrophies

http://nn.neurology.org//cgi/collection/leukodystrophies

Information about reproducing this article in parts (figures,tables) or in its entirety can be found online at:

http://nn.neurology.org/misc/about.xhtml\#permissions

Information about ordering reprints can be found online:

http://nn.neurology.org/misc/addir.xhtml\#reprintsus

Neurol Neuroimmunol Neuroinflamm is an official journal of the American Academy of Neurology.

Published since April 2014, it is an open-access, online-only, continuous publication journal. Copyright

Copyright $\left({ }^{\circ} 2020\right.$ The Author(s). Published by Wolters Kluwer Health, Inc. on behalf of the American

Academy of Neurology.. All rights reserved. Online ISSN: 2332-7812.

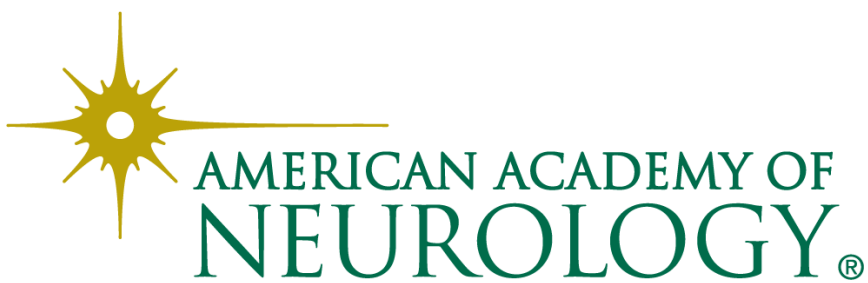

